\title{
Context and Context Meet! A Dialogue between the Sitz-im-Leben of Psalm 23 and the South African Setting
}

\author{
NDIKHO MTSHISELWA (UNISA)
}

\begin{abstract}
No doubt, Psalm 23 has stimulated a variety of scholarly conversations in OT studies. However, the bearing that this text has on the interpretation of the $H B$ in South Africa is a rarely researched area in scholarship. First, in this article the author considers the probable dating of Ps 23 in order to determine the question of the authorship and intended audience of the text in question. Second, the author attempts to reconstruct the situation of the addressees of Ps 23, and argues that the situation of the psalmist mirrors that of the addressees of the psalm, both in the late exilic and postexilic period. Third, this article draws striking parallels between the context(s) from which the text of Ps 23 emerged and the context of the modern reader of the $H B$ in South Africa. It investigates how a dialogue between the context(s) of the production of Ps 23 and that of the modern reader of the Bible may be established, and more importantly, it submits that the Sitz-im-Leben of the psalm in question could also have positive implications for South Africa.
\end{abstract}

KEYWORDS: Psalm 23, South Africa, Poverty, Corruption, Injustice, Conflict.

\section{A INTRODUCTION}

Psalm 23 is one of the most well-known psalms in the Psalter, and it is widely accepted that it is a psalm of confidence. Although there is some room to explore the theme of confidence as well as the themes of assurance, security and hospitality, with the use of the historical-critical tools, the focus here is on the reading of this psalm in the modern South African context. Various views have been expressed on approaches to the reading of the HB in the light of the modern context. Scholars such as West, Ukpong and Holter argue that both readers and their contexts constitute the subject of interpretation of the Bible in African biblical hermeneutics. ${ }^{1}$ In this hermeneutical process, the Bible is read

* Article submitted: 27 July 2015; accepted: 21 September 2015. To cite: Ndikho Mtshiselwa, "Context and Context Meet! A Dialogue between the Sitz-im-Leben of Psalm 23 and the South African Setting," Old Testament Essays (New Series) 28 no. 3 (2015): 704-723. DOI: http://dx.doi.org/10.17159/2312-3621/2015/v28n3a9

1 Gerald West, "Indigenous Exegesis: Exploring the Interface between Missionary Methods and the Rhetorical Rhythms of Africa: Locating Local Reading Resources in the Academy," NeoT 36 (2002): 153; Justin Ukpong, "Developments in Biblical 
collaboratively "with" the modern reader with the view to actualise the theological meaning of the text in today's context. ${ }^{2}$ The concern with this collaborative interpretive process is that the meaning derived from the interpretive historical-critical tools is used to construct the meaning of the text in today's context, $^{3}$ as Mtshiselwa has also confirmed. ${ }^{4}$

On the hermeneutical level, Cone writes that:

The cross and the lynching tree interpret each other. Both were pubic spectacles, shameful events, instruments of punishment reserved for the most despised people in society. Any genuine preaching of the Christian gospel must be measured against the test of the scandal of the cross and the lynching tree. Until we can see the cross and the lynching tree together, there can be no genuine understanding of Christian identity in America, and no deliverance from the brutal legacy of slavery and white supremacy. ${ }^{5}$

Cone's hermeneutical approach highlights points of convergence between the biblical text and the context of the modern readers of the Bible. In this convergence, both context and the Bible interpret each other. Worthy of note also is Cone's observation that "the cross and the lynching tree are separated by nearly two thousand years." In the same way, the context of Ps 23 and the South African context are separated by thousands of years. Thus, the question of the relevance of the biblical text to the context (or the inverse) is important. In line with Cone, the interaction between Ps 23 and the South African context would also fit in with West's call for a dialogue between the context and the biblical text. ${ }^{7}$ As Cone and West correctly perceive, both context and the Bible may interpret each other in the dialogue between the Sitz-imLeben of an ancient text and the modern context. This article does not aim to

Interpretation in Africa: Historical and Hermeneutical Directions," in The Bible in Africa: Transactions, Trajectories, and Trends (ed. Gerald O. West and Musa Dube; Leiden: Brill, 2000), 23; Knut Holter, "When Biblical Scholars Talk about 'Global' Biblical Interpretation," in Global Hermeneutics: Reflections and Consequences (ed. Knut Holter and Louis C. Jonker; Atlanta: Society of Biblical Literature, 2010), 8792.

2 Ukpong, "Developments," 24.

3 Ukpong, "Developments," 24; Ndikho Mtshiselwa, "Towards an Indigenous (Xhosa) South African Biblical Scholarship," OTE 24/3 (2011): 670.

4 Mtshiselwa, "Towards an Indigenous," 668-689.

5 James H. Cone, "Strange Fruit: The Cross and the Lynching Tree," HDB 35/1 (2007): 160; cf. James H. Cone, The Cross and the Lynching Tree (Maryknoll: Orbis Books, 2011), 52. The lynching tree refers to the execution of many an AfricanAmerican person in the United States of America.

6 Cone, Cross and the Lynching Tree, xiii.

7 Gerald O. West, "Locating 'Contextual Bible Study' within Biblical Liberation Hermeneutics and Intercultural Biblical Hermeneutics," HTS 70/1 (2014): 2. 
show how both the HB and the modern context would interpret each other in the dialogue between the context of Ps 23 and the South African setting. Although there is a room for that, this study attempts to demonstrate based on academic literature that the Sitz-im-Leben of Ps 23 could also have implications for South Africa. The discussion will follow the outline below:

- text and translation

- the date of Ps 23

- $\quad$ setting of the addressees of Ps 23

- Sitz-im-Leben of Ps 23 and the South African setting

\section{B TEXT AND TRANSLATION}

\section{Table 1: Text and translation of Psalm 23}

Hebrew

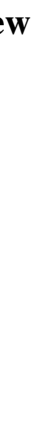

\section{Translation (mine)}

מִזממוֹר לְדְוְד A hymn of David

YְHWH is my shepherd,

I shall not be in need.

\section{Verse Strophe Stanza} 1

1a A I

$1 \mathrm{~b}$

He makes me lie down in green $2 \mathrm{a}$ pastures;

He leads me beside still waters; $2 b$

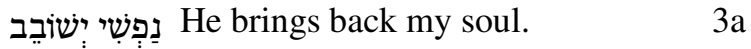

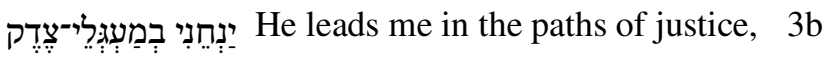

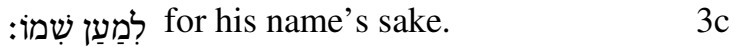

Even though I walk through the 4a valley of the shadow of death,

I fear no evil;

$4 \mathrm{~b}$

for you are with me;

$4 \mathrm{c}$

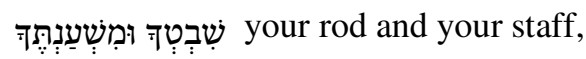

$4 d$

they comfort me.

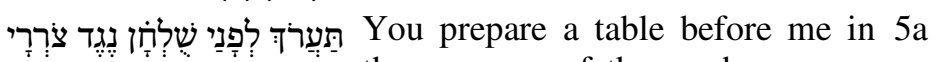
the presence of those who oppose me;

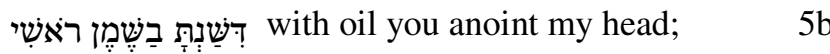

my cup overflows.

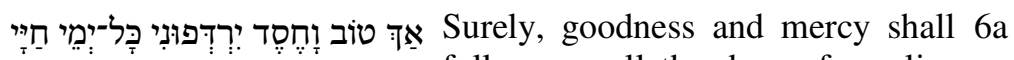
follow me all the days of my living,

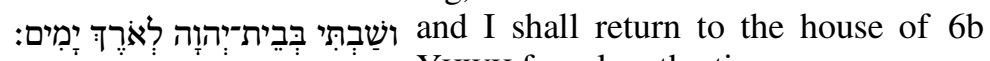
YHWH for a lengthy time.

8 Gillingham holds that this heading may be translated as a hymn or song to music. See Susan E. Gillingham, "The Levitical Singers and the Editing of the Hebrew Psalter," in The Composition of the Book of Psalms (ed. Erich Zenger; Leuven: Uitgeverij Peeters, 2010), 104. 
From a poetic analytical point of view, some remarks need to be made about the text and its translation above.

The parallels in Ps 23 give cause for many instances of rhyme in the psalm. The rhyme occurs in vv. 2, 3 and 4 through the repetition of the syllable - $n i$ ' In $\mathrm{v} .4 \mathrm{~d}$, the syllable - cha $\pi$ also creates a rhyme. In these instances, the function of the rhyme is to create a connection between the lines of poetry in vv. 2, 3, 4 which form stanza I. No doubt, the identification of rhymes assists one to determine the structure of Ps 23. Furthermore, an example of wordplay is found in vv. 2b and 3b. The repetition of the stem נינהַלְני in "he leads me" and י-נְחנִ "he leads me" points to paronomasia. Another example of wordplay is

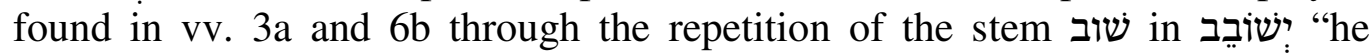
brings back" and ושַׁבְתִי "and I shall return." This establishes a connection between the verses and point out the motif of "returning." Furthermore, paro-

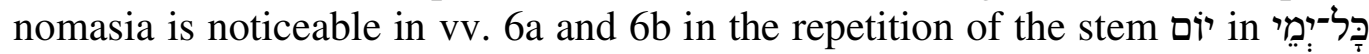
"all the days" and יִָמים "time."

From a textual critical point of view, worthy of note is the old crux of the reading of "return" (MT) or "dwell" (LXX) in v. 6b. Goldingay translates as "and I shall dwell" rather than "and I shall return." the reference to "all the days of my life" or "for a lengthy time," as suggested here, supports this position. Unlike Goldingay, Arterbury and Bellinger Jr. convincingly argue that וְַׁשְבְתִ should be translated as "and I shall return." argued that the reader of Ps 23:6 should be sympathetic to the MT and translate v. $6 \mathrm{~b}$ as "I shall return to the house of the Lord . .." as opposed to the traditional translation of "I shall dwell in the house of the Lord . . ." (NRSV)." Importantly, the rejection of Goldingay's "dwell" is first and foremost a matter of textual criticism. Both the MT and the Syriac (Peshutta Hebrew Bible) show that ישוב "return" is employed in v. 6b instead of "dwell" (cf. BHS). Grammatically, the consecutive waw ! is not attached to the verb ישב, thus the rejection of Goldingay's “dwell” (LXX) make sense. In addition, the insertion of a small dot on top of $ב$ in the BHS which means that the verb under consideration appears elsewhere in the HB enables the parallel between Gen 28:21 and Ps 23:6. This parallel supports the reading of שוב "return" in v. 6 b.

Worthy of note are the two patterns, namely, chiasm and parallelism,

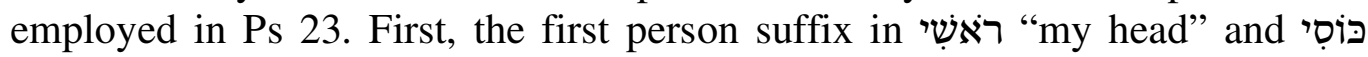
"my cup" forms a chiasmic pattern in vv. 5b and 5c. The chiasmus draws the reader of the psalm to the imagery of a feast at which the psalmist is anointed in the presence of the persons who oppose him or her. A chiasm is also formed

9 John Goldingay, Psalms (BaCOT; Grand Rapids, Mich.: Baker Academic, 2006), 345 .

10 Andrew E. Arterbury and William H. Bellinger, Jr., "'Returning' to the Hospitality of the Lord: A Reconsideration of Psalm 23:5-6," Biblica 86/3 (2005): 394.

11 Arterbury and Bellinger Jr., "Hospitality of the Lord," 395. 
by the pattern: provision (vv. 1-3), protection (v. 4), protection (v. 5), and provision (v. 6). ${ }^{12}$ This pattern renders the themes of provision and protection central to Ps 23. Second, parallelism is used throughout the psalm. Parallelism is

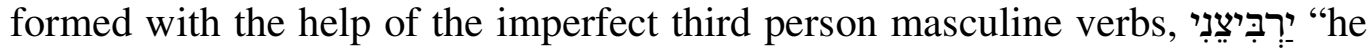

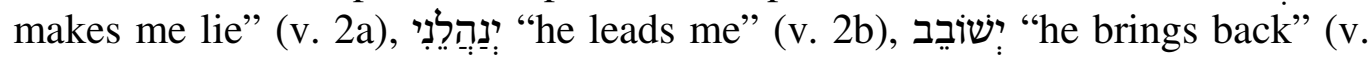

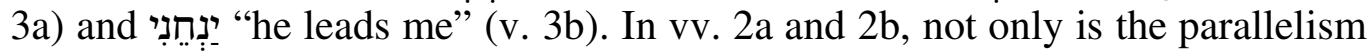
established by the preceding verbs, it is equally produced by the reference to the provision of YHWH. YHWH's provision of the psalmist's basic needs namely food and water explains why the psalmist shall not be in need (v. 1b). Interestingly, both the act of preparing the table (v. 5a) and of making the psalmist to lie down in green pastures (v. 2a) refer to the provision of food, thus producing a link between vv. $2 \mathrm{a}$ and $5 \mathrm{a}$. Furthermore, v. $1 \mathrm{~b}$ is parallel to v. $4 \mathrm{~b}$. This parallel is constructed with the help of a negative particle לא, and is set to highlight the themes of provision and protection. ${ }^{13}$ The first person singular common suffix also establishes a parallel between vv. 4c and 4e which depicts YHWH as being in the presence of the psalmist, as YHWH plays the role of both protector and comforter. This explains why the psalmist fears no evil. Thus, YHWH's role gives the psalmist reasons to trust in YHWH.

\section{THE DATE OF PSALM 23}

As Gerstenberger has argued, the Book of Psalms was constructed in various phases namely the early pre-exilic phase, the later pre-exilic phase, the exilic phase and the postexilic phase. ${ }^{14}$ Certain unidentified collections of psalms and liturgies originated in the early pre-exilic phase, whilst the Korahite collection (Pss 42-49), the Asaphite collection (Pss 78-83), the Yahweh enthronement psalms (Pss 96-99), the Hallelujah psalms (Pss 111-118) and the Psalms of Ascent (Pss 120-134) originated in the later pre-exilic phase. Furthermore, Gerstenberger holds that a few Davidic collections (Pss 3-41, 51-72, 108-110, 138145) were added to the Psalter during the exile. ${ }^{15}$ In the postexilic phase, the Korahite and the Davidic collections were grouped to form the five books of the Psalter. Based on the view that "the Korahite and Asaphite psalms were used as 'backbone' by the early Levites to construct the postexilic liturgical hymnbook," Jonker affirms Gerstenberger's view that the Davidic collections

12 Arthur G. Clarke, Analytical Studies in the Psalms (Grand Rapids, Mich.: Kregel Publications, 1979), 78-79.

13 Cf. William P. Brown, "'Here Comes the Sun!' The Metaphorical Theology of Psalms 15-24," in The Composition of the Book of Psalms (ed. Erich Zenger; Leuven: Uitgeverij Peeters, 2010), 265.

14 Erhard S. Gerstenberger, Psalms: Part I with an Introduction to Cultic Poetry (Grand Rapids, Mich.: Wm. B. Eerdmans Publishing Co., 1988), 29; Louis C. Jonker, "Revisiting the Psalm Headings: Second Temple Levitical Propaganda," in Psalms and Liturgy (ed. Dirk J. Human and Cas J. A. Vos; London: T\&T Clark International, 2004), 110.

15 Gerstenberger, Psalms 1, 29. 
(particularly Pss 3-41) originated during the exile in Babylonia. ${ }^{16}$ Specifically, a late exilic date for the Book therefore appears to make sense.

As noted above, the repetition of the stem שישיָוֹבב in "he brings back" and ושַׁבְתִ "and I shall return" indicates the theme of "returning" in Ps 23. Although the reading of "return" (MT) or "dwell" (LXX) in v. 6b is a matter of textual criticism, it however fits in the discourse of the dating of Ps 23. The discussion of "returning," particularly, to the homeland fits with the late exilic period, just before the actual return of the exiles. ${ }^{17}$ In this case, the idea of returning to the homeland and to the house of YHWH - the Temple - was necessary in a situation of captivity, and it would be reasonable to posit a late exilic date for Ps 23. The use of the verb שוב "to return" in the late exilic texts may supports the late exilic dating of that psalm (cf. Jer 29:14; 30:3).

First and foremost, both Jonker and Gillingham ascribe Ps 23 to the Levitical singers rather than to the psalmody. ${ }^{18}$ This is based on the view that the liturgical heading, "A hymn of David" suggests a Levitical influence. Furthermore, it is argued that Ps 23 was one of the psalms which the Levites sang in the Second Temple. ${ }^{19}$ Postexilic literature supports the argument that the Levites emerged as singers (cf. Ezra 2:40-70; Neh 7:43-73). Although the use of the verb שוב "to return" is noticed in the late exilic literature, as shown above, it is equally observed in the postexilic texts (cf. Gen 28:21; Eccl 4:1). The theme of "returning" also occurs in prophetic literature linked to the postexilic promise of the return to the land (cf. Jer 23:5; 32:37; 33:16; Ezek 28:26; $34: 25,28 ; 38: 8,11,14 ; 39: 26)$. Given the textual evidence as well as the noticeable influence of the Levites in the Second Temple, a postexilic dating of Ps 23 is reasonable. Furthermore, based on the content of the psalm, Gillingham argues that the presence of YHWH with his people (cf. Ps 23:4) suggests that the Levitical singers now have in mind the Second Temple community which was not located within a monarchical setting. ${ }^{20}$

From the abovementioned arguments based on theme and content, both the exilic and the postexilic dating of Ps 23 appear plausible. The psalm probably originated in the late exilic period and it was later recited in the postexilic setting.

16 Jonker, "Revisiting," 111; cf. Gerstenberger, Psalms 1, 29.

17 Baruch J. Schwartz, "'Profane' Slaughter and the Integrity of the Priestly Code," HUCA 67 (1996): 36; Walter Brueggemann, An Introduction to the Old Testament: The Canon and Christian Imagination (Louisville, Ky.: Westminster John Knox Press, 2003), 113; Esias Meyer, "Returning to an Empty Land: Revisiting My Old Argument about Jubilee," OTE 27/2 (2014): 505.

18 Gillingham, "Levitical Singers," 103.

19 Gillingham, "Levitical Singers," 105-106; cf. John A. Smith, "Which Psalms Were Sung in the Temple?" M\&L 71 (1990): 180-181.

20 Gillingham, "Levitical Singers," 102. 


\section{POSSIBLE SETTING OF THE ADDRESSEES OF PSALM 23}

It has been argued that 2 Sam 15-19 mirrors the Sitz-im-Leben of Ps 23 in that the psalm refers to David's flight from Jerusalem when Absalom revolted against him. ${ }^{21}$ However, it is difficult to make clear linguistic and thematic connections between the texts of Ps 23 and 2 Sam 15-19. Thus, the view that the events recorded in 2 Sam 15-19 mirror the setting of Ps 23 is implausible. In addition, Goulder has suggested that Ps 23 may well have been written after David's victory in the Valley of Baal-Perazim and his subsequent anointing as king in 2 Sam $5 .^{22}$ The argument that there is no clear thematic and linguistic connection between the texts of Ps 23 and 2 Sam 5 also holds regarding Goulder's suggestion. As such, it would be helpful to search for clues about the addressees of the psalm in the text as well as in the late exilic and postexilic biblical literature. An investigation of the psalm will now be conducted.

\section{The Issue of Poverty}

Based on the theme of provision which is noticeable in Ps 23 one wonders whether the Jews experienced a need for the provision of bread during the time in which the psalm was composed. If that is the case, can one read such a need as a clue about hunger or poverty? From an intertextual point of view, the verb חסר "be in need" is employed in the postexilic texts to portray a situation

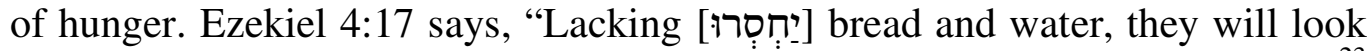
at one another in dismay, and waste away under their punishment" (NRSV). ${ }^{23}$ Nihan has argued convincingly that a postexilic date for the composition of the Book of Ezekiel is plausible. ${ }^{24}$ Thus, it is clear that the issue of hunger - the need for food - was a concern for both the author and addressees of the psalm in postexilic Yehud. Furthermore, the verb חסר "be in need" is also used in Judg 19:19 in relation to the provision of bread. It is generally accepted that the composition of the Book of Judges occurred in the exilic and/or the postexilic period (c. 587-398 B.C.E.). ${ }^{25}$ In this period, the author of the Book of Judges

21 Jack R. Lundbom, "Psalm 23: Song of Passage," Int 40 (1986): 12-14; Stewart J. J. Perowne, The Book of Psalms (4th ed.; Grand Rapids, Mich.: Zondervan, 1966), 249.

22 Michael Goulder, "David and Yahweh in Psalms 23 and 24," JSOT 30/3 (2006): 469.

23 In this instance, the NRSV is consulted for a clearer translation of the text in question.

24 Christophe Nihan, "The Memory of Ezekiel in Postmonarchic Yehud," in Remembering Biblical Figures in the Late Persian and Early Hellenistic Periods: Social Memory and Imagination (ed. Diana V. Edelman and Ehud Ben Zvi; Oxford: Oxford University Press, 2013), 415-417.

25 Cheryl J. Exum, "Judges," in Harper's Bible Commentary (ed. James L. Mays; San Francisco: Harper \& Row Publishers, 1988), 245-261; Madipoane Masenya 
imagines a situation in which the text's addressees will not experience hunger. Job 30:3 which OT scholars consider to be postexilic is also worthy of note. ${ }^{26}$

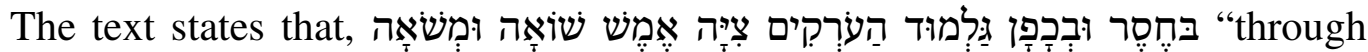
want and hard hunger they gnaw the dry and desolate ground" (NRSV). The text of Job 30:3 also mirrors a setting in which the issue of hunger was prevalent.

Interestingly, in Deut 28:48, the verb חסר "be in need" is attached to the

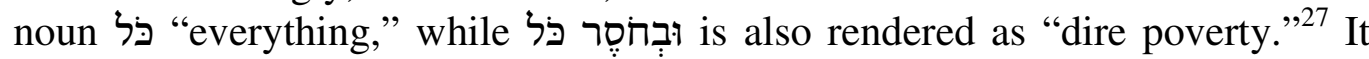
מסר becomes clear that the suggestion of hunger that is contained in the verb "be in need" may be sufficient to validate the supposition that the addressees of Ps 23:1 experienced poverty. Elsewhere in the exilic text of 1 Sam 2:8, YHWH is portrayed as one who alleviates poverty (cf. Ps 113:7). Hutton attributes the combination of Samuel and Kings to the Deuteronomistic first edition of the Deuteronomistic History (DH) and subsequently the dating of the Books of Samuel to the exile. ${ }^{28}$ It is remarkable that the text of 1 Sam 2:8 depicts YHWH as not only redeeming the poor from poverty, but also elevating the poor to a position of political power as princes. In this instance, an economic condition is linked to a political situation. In other words, the alleviation of poverty is linked to the elevation to a position of political power. Often, when such a link occurs, it is presupposed that there is economic exploitation of the poor by the political élites. It is no wonder that the Jewish exiles in Babylon were exploited economically particularly in the sense that they served as sources of cheap labour. $^{29}$ Exilic Davidic psalms specifically Pss 41 and 72 also allude to the issue of poverty. Psalm 41:1 says, "Happy are those who consider the poor . .." whilst Ps 72:13, "He shall spare the poor and needy, and shall save the souls of the needy," connects the restoration of the "soul" נֶפטש to poverty alleviation. The fact that Ps 23:3 equally makes reference to the restoration of the "soul," and to poverty accounts for the connection drawn between Pss 72:13 and 23:3.

(ngwan'a Mphahlele), "Sacrificing Female Bodies at the Altar of Male Privilege: A Bosadi (Womanhood) Reading of Judges 19," JTRA 27/1 (2003): 100.

26 Harold H. Rowley, “The Book of Job and Its Meaning," BJRL 41 (1958): 197; Norman C. Habel, The Book of Job: A Commentary (Philadelphia: Westminster Press, 1985), 40-42; John E. Hartley, The Book of Job (Grand Rapids, Mich.: Wm. B. Eerdmans Publishing Co., 1988), 17; Shmuel Vargon, "The Date of Composition of the Book of Job in the Context of S.D. Luzzatto's Attitude to Biblical Criticism," JQR 91/3-4 (2001): 377.

27 The NIV translation of the Bible is used here.

28 Jeremy H. Hutton, The Transjordanian Palimpsest: The Overwritten Texts of Personal Exile and Transformation in the Deuteronomistic History (Berlin: Walter de Gruyter GmbH \& Co. KG, 2009), 141-142.

29 Daniel L. Smith, The Religion of the Landless: The Social Context of the Babylonian Exile (Bloomington: Meyer Stone Books, 1989), 38-41; Daniel L. Smith-Christopher, A Biblical Theology of Exile (Minneapolis: Fortress Press, 2002), 71-73; cf. Isa 52:5; Jer 51:6-7; Lam 3:1-9; Ps 137. 
The interpretation of Ps 23 in the light of the exilic and postexilic literature shows that the addressees of the psalm likely experienced poverty.

\section{A Glimpse at Corruption}

Some scholars regard Pss 16 and 23 as twins, ${ }^{30}$ and for this reason it is easy to

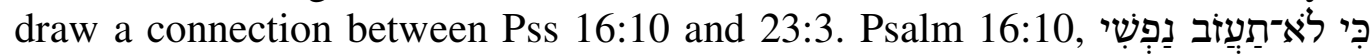
For you do not leave my soul at Sheol; neither do you let your Holy One see corruption, ${ }^{, 31}$ strikes a parallel with Ps

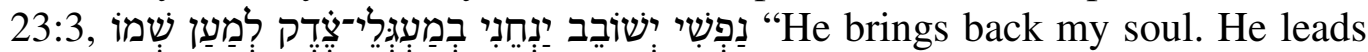
me in the paths of justice, for his name's sake." Not only are the two verses linked by the reference to the "soul," but also by the portrayal of YHWH as the restorer of the soul of the psalmist. A major difference between the two verses is the fact that the concluding phrase in Ps 23:3, "for his name's sake" is lacking in Ps 16:10. In addition, a reference to שָׁח "corruption" is made in Ps

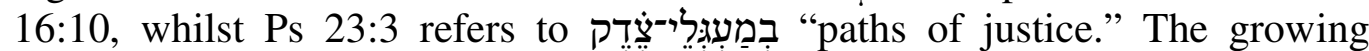

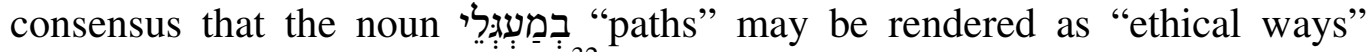
draws the two references closer. ${ }^{32}$ In Ps 16:10, the act of preventing the Holy One from seeing "corruption" is comparable to that of leading one along "ethical ways" in Ps 23:3. Given the connection between Pss 16:10 and 23 noted here, particularly with regard to the nouns "corruption" and "paths/ethical ways," one could argue that the addressees of Ps 23 also experienced corruption which caused the composer of the psalm to state that YHWH led him or her in the "paths/ethical ways" of justice. However, in this psalm, the composer is not explicit about the form of corruption. Thus, it may be helpful to consider also the connection between Pss 23 and $24 .^{33}$

The noun נקֶפש "the soul" links Pss 24:4; $23: 3$ and 16:10, and incidentally, all three verses allude to corruption. The mention of "clean hands,"

30 Alphonso Groenewald, "Ethics of the Psalms: Psalm 16 within the Context of Psalms 15-24," JSem 18/2 (2009): 426.

31 In the OT, the noun שָָׁ shachath is translated either as corruption, pit or destruction or as ditch or grave. This is a significant textual problem; and rather than assuming that the text of Ps 16:10 is referring to the issue of "corruption" a brief critical look at the noun is in order. The NKJV render shachath as "corruption," whilst the NRSV presents the noun as "pit." If one considers the reference to the "paths of life" or "ethical ways of life" in Ps 16:11 as well as an allusion to ethical ways in Ps 23, a reading of shachath as likely referring to corruption, as the NKJV tradition suggests, may be reasonable.

32 Nancy L. deClaissé-Walford, “An Intertextual Reading of Psalms 22, 23, and 24," in The Book of Psalms: Composition and Reception (ed. Peter W. Flint and Patrick D. Miller, Jr.; Leiden: Brill, 2005), 151; Groenewald, "Ethics of the Psalms," 428.

33 For the connection between Pss 23 and 24 see DeClaissé-Walford, "Intertextual Reading of Psalms," 151; Phil J. Botha, "Answers Disguised as Questions: Rhetoric and Reasoning in Psalm 24," OTE 22/3 (2009): 536, 551. 
"pure hearts," that which is "false," and "deceit" points to the presence of corruption. If we consider the modern definition of corruption as the abuse of public power for private benefit, that is, the deceitful use of a position of trust for dishonest gain, the view that Ps $24: 4$ suggests corruption may be valid. ${ }^{34}$ Interestingly, the "paths/ethical ways," in Pss 16:10 and 23:3 imply both the principle of honesty and of justice. ${ }^{35}$ The connection made here between Pss $24: 4 ; 23: 3$ and 16:10 suggests that Ps $23: 3$ contains a clue about the corruption which was experienced by the addressees of the Levitical singers.

In view of the allusion to corruption in Ps 23, an illustrative discussion of corruption in the late exilic and/or the postexilic period may be warranted. Because the psalm does not offer a detailed account (perhaps limited by its genre), but clues about possible situation of its addressees, it may be worth our while to investigate such situation(s) in other texts which were composed around the time in which the psalm was composed. A postexilic text Neh 5:7 shows that Nehemiah laid charges against the political élites namely the nobles and rulers because they coerced the poor to pay additional money to them besides the tax which was due to King Artaxerxes. The charge opposed the deceitful use of public power for the private benefit of the nobles and the rulers. In line with Neh 5:7, McNutt rightly argues that the heavy taxes supported the local élites and the Persian Empire in postexilic Yehud. ${ }^{36}$ Furthermore, Nehemiah laid a charge against the corrupt officials who engaged in trading in slaves. Nehemiah 5:8 says, ". . . now you are selling your own kin, who must then be bought back by us." In this case, the officials - political élites - who formed part of Nehemiah's government privately generated money for themselves by selling poor Jews to other nations, who would subsequently be repurchased by the government of Nehemiah. Thus, McNutt notes the possibility of the pursuit of personal gain on the part of the political élites in the system of exchange and trade in the postexilic period. ${ }^{37}$ If corruption is the deceitful use of a position of power for dishonest gain, surely, the practice of trading people with the knowledge that the government would repurchase them should be viewed as corruption.

It must be said though that one may view the corruption that is referred to in Pss 23 and 16 as having nothing to do with the corruption in government. But, what if that is the case because the psalm merely gives clues? What is certain though is the reality that other postexilic text gives both the clues and details about corruption in the postexilic period. In this case, one may be of the

34 Vito Tanzi, "Corruption around the World: Causes, Consequences, Scope, and Cures," IMF 45/4 (1998): 564.

35 Groenewald, "Ethics of the Psalms," 428.

36 Paula McNutt, Reconstructing the Society of Ancient Israel (Louisville, Ky.: Westminster John Knox Press, 1999 / London: SPCK, 1999), 197.

37 McNutt, Reconstructing, 195. 
opinion that it appears as if Ps 23 is being made to fit into the postexilic context which is describing here. However, it may no be unreasonable to explore the context of the texts which seem to be related to the psalm and subsequently draw deduction about the situation or context of both the Ps 23 and the text investigated, namely, Neh 5. Both these texts make an allusion to corruption, but are different in terms of the details.

\section{Injustices Experienced by the Addressees}

On a linguistic level, the noun צֶדְק "tsedeq" employed in Ps 23:3 is often rendered in different ways in various translations of the HB. For example, in Deut

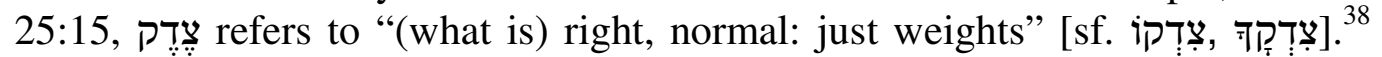
However, צֶדָק also means "(legal) rightness" (cf. Deut 16:20). It should be noted that the NRSV and the NIV render צֶדק in Deut 16:20 as "justice," and in Deut 1:16, צֶדָק is also translated as "justice" (cf. Deut 16:18). Additionally, צֶדְק may also mean "justice done to someone" (cf. Isa 41:2). Interestingly, deClaissé-Walford translates this noun צִידק in Pss 23:3 and 24:5 as "justice" rather than "righteousness." "39 The reference to deceitfulness in Ps 24:4 as well as the allusion to the unfair treatment implied in the expressions, "walk through the valley of the shadow of death," "being comforted," and the "presence of my enemies" in Ps 23, justifies the translation of the noun as "justice." Thus, it is fairly certain that in the context of Ps 23 the noun צִדָק means "justice," and one could reasonably argue that the addressees of the Levitical singers experienced some form of injustice which necessitated the reference to justice in Ps 23:3.

Various forms of injustice were perpetrated in the late exilic and/or postexilic period ranging from the exploitation of the poor through heavy taxation to the creation of situations of indebtedness for the poor, as well as the confiscation of the land owned by the poor, and slavery. On the issue of the exploitation of the poor, McNutt remarks:

Regardless of who owned the majority of the land, the economic well-being of the local population in Persian-period Judah seems to have declined progressively over time, with the development of a high degree of poverty, particularly in rural areas, resulting in some cases in an inability to pay off debts, and consequently the necessity of selling off land to the more wealthy. This was likely caused in part by the Persian government's depletion of the rural economy through heavy taxation, and in part by the fact that the taxes had to support the local élites as well as the empire. ${ }^{40}$

38 For the translation of צֶדק as "what is right," see also Isa 45:19. See the Bible Works 8 programme.

39 See DeClaissé-Walford, "Intertextual Reading," 150.

40 McNutt, Reconstructing, 196-197. 
McNutt's view is confirmed by Neh 5:10-12 which refutes the exploitation of the poor in terms of the system of heavy taxation as well as the issues of indebtedness, land use and slavery. The passage also attests to the injustice experienced by the Jews in postexilic Yehud.

\section{Conflict in the Postexilic Yehud Community}

Zenger holds that the "psalm of confidence" namely Ps 23 has its Sitz-im-Leben mostly in a situation of conflict, argumentation and attack. "evil" (v. 4b) and the qal verb which is attached to a singular suffix, צִרְרָי "those who oppose me" (v. 5a) support Zenger's position. Verses 4b and 5a allude to conflict. In addition, the noun צַלְמָוֶת "shadow of death" (cf. v. 4a) carries the insinuation of an attack. Based on the connection between vv. 4 and 5, and more particularly with regards to the phrase "those who oppose me" it may be said that the Levitical singers had a situation of conflict and of hostility in mind. Thus, the view that the addressees of Ps 23 also experienced conflict is justified.

As mentioned earlier, the theme of "returning" in Ps 23 fits the late exilic and postexilic period. Therefore, probing the attitude towards the exilic returnees in postexilic Yehud might prove helpful in the discussion of the conflict in the postexilic community. Römer correctly points out that the Persian ideology of segregation created a distinction between persons based on class and identity. ${ }^{42}$ The distinction between the walled cities and village houses which clearly marked a distinction between the Golah élites (who returned from the Babylonian exile) and the people of the land (the poor from rural Yehud) supports this view. ${ }^{43}$ Furthermore, some scholars point out that throughout the Monarchic, Neo-Assyrian, and Neo-Babylonian periods and even during the Persian period, large portions of agricultural land which produced wealth were owned by the rich and powerful élites who resided in the cities. $^{44}$ Thus, the rich élites most likely lived in cities whose productive land was managed by the poor Israelites. Given the issue of classism, economic inequality and the adverse treatment of the poor from rural Yehud, McNutt's observation of the conflict between the returning exiles and those who remained in Yehud namely the so-called "people of the land" would make sense. $^{45}$

41 Erich Zenger, Die Nacht wird leuchten wie der Tag: Psalmenauslegungen (Freiburg: Herder, 1997), 219.

42 Thomas Römer, The So-called Deuteronomistic History: A Sociological, Historical and Literary Introduction (London: T\&T Clark International, 2005), 169, 171.

43 See Lev 25:29-34.

44 Douglas A. Knight, Law, Power and Justice in Ancient Israel (Louisville, Ky.: Westminster John Knox Press, 2011), 202.

45 McNutt, Reconstructing, 200-202. 
Based on Ps 23, several late exilic and postexilic texts, as well as findings from OT scholarship, it becomes fairly certain that the addressees of the Levitical singers in this psalm experienced poverty, corruption, injustice and conflict. It is in the light of these issues that we consider a dialogue between the Sitz-im-Leben of Ps 23 and the South African setting.

\section{E SITZ-IM-LEBEN OF PSALM 23 AND THE SOUTH AFRICAN SETTING}

As mentioned above, the present article aims to establish a dialogue between the context(s) of the production of Ps 23 and the context of the modern reader of the HB. It is assumed that the Sitz-im-Leben of Ps 23 could have implications for South Africa, specifically in relation to the issues of poverty, corruption, injustice and conflict.

\section{Poverty}

The view that the issue of hunger - need for food - was a major cause of conflict in postexilic Yehud not only shed light on the experiences of the addressees of Ps 23, it also calls to mind the experiences of poverty in post-apartheid South Africa. According to the General Household Survey (GHS) data from 2002 to 2011, released by Statistics South Africa (Stats SA), "the poorest 40 percent of households on average received an income of less than R650 per person per month while the poorest 20 percent of households earned less than R325 per person per month." ${ }^{, 46}$ On average, 61.4 percent of poor people in South Africa are black compared to 4.35 percent of white. ${ }^{47}$ In addition to the index on poverty, Stats SA also offers data on racial inequality in South Africa. In terms of gender inequality and poverty, 55.2 percent of women lived in poor households as opposed to approximately 50 percent of men in $2012 .^{48}$ Of the 55.2 percent of women, approximately 50 percent are black, 5 percent are white and 10 percent are Indian/Asian whilst 35 percent are coloured. ${ }^{49}$ Although the literature on Ps 23 does not identify the approximate percentage of Jews who were poor in both the late exilic and the postexilic period, the statistics on poverty in South Africa is available. Thus, it may be deduced that in both contexts (i.e. the context of the production of Ps 23 and the South African setting) the issue of poverty was and is a reality. Enthused by Ps 23, the issue of poverty in post-apartheid South Africa could be viewed as an urgent concern for the poor. Thus, the positive implication that YHWH will administer provision to the most oppressed South Africans, namely women and black persons, is critical in the context of poverty alleviation. Based on Ps 23, the issue of the

46 Statistics South Africa (Stats SA), Social Profile of Vulnerable Groups in South Africa 2002-2011 (Pretoria: Statistics South Africa, 2012), 13.

47 Stats SA, Social Profile, 71.

48 Stats SA, Social Profile, 71.

49 Stats SA, Social Profile, 71. 
provision of food as well as food security needs to be a continuing priority for both the ecclesiastic community and local governments.

As argued above, the alleviation of poverty is linked to the elevation of the poor to a position of political power in Ps 23, which presupposes a situation in which the poor were exploited by the political élites. On the experiences of the addressees of Ps 23, one would say that the reality of the alleviation of poverty as inseparable from political liberation in the late exilic and postexilic periods reminds one of the situation in South Africa. The argument that "the end of political apartheid is ultimately meaningless without the end of economic apartheid" shows that the issue of political liberation is inseparable from the alleviation of poverty or economic liberation in South Africa. ${ }^{50}$ Thus, Klein's statement that black South Africans were "given the key to the house, but not the combination to the safe" suggests that South Africa's liberation is not complete since the poor continue to pursue economic freedom. ${ }^{51}$ From the parallels drawn here, a reading of Ps 23 that highlights the issue of poverty as well as the link between poverty alleviation and political liberation would enjoy a positive reception in South Africa particularly among poor black South Africans. Thus, the text of Ps 23 bears a positive implication to the South African context because it demands the elevation of the poor to a position of political power in order to prioritise poverty alleviation.

\section{Corruption}

The issue of corruption that is inferred in Ps 23 which is highlighted here triggers a debate on corruption in the context of South Africa. The inference also hints at the positive implication that Ps 23 may bear to the most oppressed South Africans. As shown above, the officials of Nehemiah's government were charged for unduly benefiting from the payment of taxes in postexilic Yehud. These officials privately generated money for themselves by selling poor Jews to other nations. However, since there is no evidence that the officials of the South African Revenue Service (SARS) divert additional tax money to their private bank accounts, South Africans may not identify with the point that the officials of Nehemiah's government unduly benefitted from the payment of taxes in postexilic Yehud. Nonetheless, the misuse of power by the political élites for the purpose of privately enriching themselves is also expressed in the South African setting. Newham remarks that:

... the public are aware that politicians and public officials divert public funds away from service delivery into their back pockets. In

50 Joseph Edozien, "Ending Economic Apartheid," 1 [cited 20 February 2014]. Online: http://www.sane.org.za/docs/eeashortversion.pdf.

51 Naomi Klein, "Democracy Born in Chains: South Africa's Constricted Freedom," in The Shock Doctrine: The Rise of Disaster Capitalism (ed. Naomi Klein; New York: Metropolitan Books, Henry Holt and Company, LLC, 2007), 204. 
2011 the former head of the Special Investigation Unit, Willie Hofmeyer, reported before parliament that between R25 billion and R30 billion was lost to the government procurement budget each year due to this type of fraud. ${ }^{52}$

Similarly, Ndaliso's report on corruption among politicians and public officials shows that a KwaZulu-Natal businessman Roshen Sewpersadh and three government officials Promise Phumzile Makhanya, Bhekumuzi Patrick Masoka and Sibusiso Chapi were arrested for irregular awarding and administration of land reform grants but were released on bail. ${ }^{53}$ Thus, the issue of corruption in the context of the addressees of Ps 23 elicits the discourse on corruption in South Africa. However, a mere acknowledgement of the preceding parallels is not enough because it does not tease out the positive implications that the Sitz-im-Leben of Ps 23 has for post-apartheid South Africa.

If read in the South African context, an allusion to corruption in Pss 23 and 16 and the reference to "ethical ways" in Ps 23:3 as well as the mention of "clean hands," "pure hearts," that which is "false," and "deceit" in Pss 24:4 challenges the modern reader of the HB to be critical of any form of corruption. The positive implications that YHWH will administer ethical ways demand of the oppressed South Africans to expose forms of corruption among politicians and public officials.

The dialogue between the context of the production of Ps 23 and the modern South African setting should consider not only striking parallels but also points of divergence between the two contexts. Thus, it is aforementioned that the selling of slaves in Yehud has no counterpart in South Africa. The reader of Ps 23 in the South African context may not identify with the display of corruption by the officials of Nehemiah's government as they privately generated money for themselves by selling poor Jews to other nations. The reason for is that trading in slaves is not practiced in the postcolonial and post-apartheid South Africa.

52 Gareth Newham, "Why is Corruption Getting Worse in South Africa?" 1 [cited 15 March 2015]. Online: http://www.corruptionwatch.org.za/content/why-corruptiongetting-worse-south-africa.

53 Chris Ndaliso, "Land Fraud Case Set for 2012," The Witness (3 October 2011): 1; cf. Eddie Mohoebi, Forfeiture Unit Seizes 2 KwaZulu-Natal Farms as Department Intensifies its Fight Against Fraud and Corruption (Pretoria: DRDLR, 2011), 1-3; Jacob G. Zuma, Written Replies by President Zuma Submitted to Parliament: 30 September 2012 (Pretoria: The Presidency, Republic of South Africa, 2012), 2. 


\section{$3 \quad$ Injustice}

As noted above, various forms of injustice in the late exilic and/or postexilic period ranged from the exploitation of the poor through heavy taxation to creating situations in which the poor became indebted, the confiscation of the land owned by the poor, and slavery. On the issue of injustice experienced in the late exilic and/or postexilic period and in modern South Africa, we now focus on the challenge of indebtedness and the confiscation of the land.

First, the challenge of indebtedness experienced in the late exilic and postexilic period triggers the interest in the debts accumulated by the workingclass people of South Africa. As Mtshiselwa has noted, indebtedness among the working-class people of South Africa constitutes a form of oppression. ${ }^{54}$ The South African working-class seems to be perpetually trapped in debt. Many of "the cars and the houses that many middle-class workers possess belong to the banks, and not to them." fore could be compared to the indebtedness of the working-class people in South Africa. Based on the textual evidence of the challenge of indebtedness experienced in the late exilic and postexilic period, the latter comparison helps us to understand the noun צִ צt "tsedeq" employed in Ps 23:3 as probably addressing the issue of injustice. ${ }^{56}$ In the South African context, the implications that YHWH will administer justice "tsedeq" may be read as a call to the ministry of finance, South African Reserve Bank as well as Banks to consider to reduce the interest rates for loans. Such a consideration would be a step towards showing a concern about the indebtedness of working-class people and the poor in South Africa.

Second, the confiscation of the land owned by the poor Jews in the world of the production of Ps 23 reminds one of the confiscation of land owned by black South Africans during the colonial and apartheid regime in South Africa. Since "the land which was confiscated from black South Africans by the white (British) colonists continues to be, by and large, in the hands of white South Africans," the issue of the confiscation of land owned by the poor Jews becomes relevant in the South African context. ${ }^{57}$ In this case, the context(s) of the production of Ps 23 tallies with the South African context as the issue of the confiscation of land is attested in both contexts. The link between poverty and the loss of land by the poor to the economic oligarchs and political élites in

54 Ndikho Mtshiselwa, “A Post-apartheid Nation in Chains? Relevance of Lucky Dube's Mickey Mouse Freedom in Reconfiguring Forms of Oppression in South Africa Today," StHistE 40/1 (2014): 71.

55 Mtshiselwa, "Post-Apartheid Nation," 71.

56 Cf. Neh 5:10-12.

57 Ndikho Mtshiselwa, “A Re-Reading of 1 Kings 21:1-29 and Jehu's Revolution in Dialogue with Farisani and Nzimande: Negotiating Socio-economic Redress in South Africa," OTE 27/1 (2014): 212. 
Yehud helps us to understand and sympathise with the view that the issue of poverty in South Africa is connected to the loss of land. ${ }^{58}$ For instance, as Modise and Mtshiselwa observed, poverty is a legacy of the Natives Land Act of 1913 which contributed to the manner in which black South Africans loss their productive land. ${ }^{59}$ If not addressed, the issue of poverty and land could continue to be the crux of conflict in South Africa.

\section{Conflict}

As shown above, the conflict between the rich élites who returned from exile in Babylonia and the poor Jews who remained in Yehud provides a plausible lifesetting for Ps 23. Interestingly, not only was the conflict fuelled by the existing power dynamics in the society but also by the economic inequalities in postexilic Yehud, that is, the conflict was between the rich and the poor. The gap between the rich and the poor is also evident in South Africa. Therefore, both the gap and the conflict between the rich élites and the poor in postexilic Yehud prompt a closer look at the recurrent protests against low wages by labourers in the South African mines and farms. ${ }^{60}$ Masenya (ngwan'a Mphahlele) ascribes such protests to the perpetual cycle of poverty which was inherited from the inequities of the apartheid era. Her point is valid, but if one considers the gap and the conflict between the rich élites and the poor in postexilic Yehud, it becomes clear that at issue in the protests against low wages is the disturbing reality of economic inequality. Moreover, the context of the addressees of Ps 23, particularly regarding the conflict between the rich élites who returned from exile and the poor Jews causes one to view the protest against low wages in South Africa as a portrayal of the gap and the conflict between the rich and the poor.

Furthermore, the inability to address the gap between the rich and the poor in postexilic Yehud (cf. Neh 2:8, 15, 17; 3:8, 13; 4:1, 3, 6) tallies with the post-apartheid South African situation where such a gap is confirmed by the increasingly high level of poverty. This means that the conflict between the rich and the poor in South Africa also continues to grow.

\section{F CONCLUSION}

This article set out to consider a dialogue between the context(s) of the production of Ps 23 and that of the modern reader of the Bible. The remarks made

58 McNutt links the issue of poverty and loss of land in Yehud. See McNutt, Reconstructing, 196-197.

59 Leepo Modise and Ndikho Mtshiselwa, "The Natives Land Act of 1913 Engineered the Poverty of Black South Africans: A Historico-ecclesiastical Perspective," StHistE 39/2 (2013): 376.

60 Madipoane Masenya (ngwan'a Mphahlele), "Eating the Louse and Its Larva! The Indignity of Poverty as Embedded within Selected African and Old Testament Proverbs," Scriptura 111/3 (2012): 453. 
from a poetic analytical point of view about the text and the translation as well as the dating of Ps 23 offer helpful insight about the possible setting of the addressees of the psalm. Whereas issues of poverty, corruption, injustice and conflict are examined, the discussion also extends to the interaction between the Sitz-im-Leben of Ps 23 and the South African setting. We have shown that not only are there striking similarities between the world(s) of the production of Ps 23 and the South African context, but both contexts also differ in certain ways. The article further shows that the context(s) of the psalm in question triggers and influences the debate on poverty, corruption, injustice and conflict in South Africa. In the end, and more importantly, the author submits that the Sitz-im-Leben of Ps 23 has positive implications for the post-apartheid South Africa.

\section{BIBLIOGRAPHY}

Arterbury, Andrew E. and William H. Bellinger, Jr. " "Returning' to the Hospitality of the Lord: A Reconsideration of Psalm 23:5-6.” Biblica 86/3 (2005): 387-395.

Bibleworks 8. The Premier Biblical Exegesis and Research Program, [s a]. Bigfork: Hermeneutika.

Botha, Phil J. "Answers Disguised as Questions: Rhetoric and Reasoning in Psalm 24." Old Testament Essays 22/3 (2009): 535-553.

Brown, William P. "'Here Comes the Sun!' The Metaphorical Theology of Psalms 15-24." Pages 259-278 in The Composition of the Book of Psalms. Edited by Erich Zenger. Leuven: Uitgeverij Peeters, 2010.

Brueggemann, Walter. An Introduction to the Old Testament: The Canon and Christian Imagination. Louisville, Ky.: Westminster John Knox Press, 2003,

Clarke, Arthur G. Analytical Studies in the Psalms. Grand Rapids, Mich.: Kregel Publications, 1979.

Cone, James H. "Strange Fruit: The Cross and the Lynching Tree." Harvard Divinity Bulletin 35/1 (2007): 46-55.

. The Cross and the Lynching Tree. Maryknoll: Orbis Books, 2011.

DeClaissé-Walford, Nancy L. "An Intertextual Reading of Psalms 22, 23, and 24." Pages 139-152 in The Book of Psalms: Composition and Reception. Edited by Peter W. Flint and Patrick D. Miller, Jr. Leiden: Brill, 2005.

Edozien, Joseph. "Ending Economic Apartheid.” Page 1. Cited 20 February 2014. Online: http://www.sane.org.za/docs/eeashortversion.pdf.

Exum, Cheryl J. "Judges." Pages 245-261 in Harper's Bible Commentary. Edited by James L. Mays. San Francisco: Harper \& Row Publishers, 1988.

Gerstenberger, Erhard S. Psalms: Part I with an Introduction to Cultic Poetry. Grand Rapids, Mich.: Wm. B. Eerdmans Publishing Co., 1988.

Gillingham, Susan E. "The Levitical Singers and the Editing of the Hebrew Psalter." Pages 91-124 in The Composition of the Book of Psalms. Edited by Erich Zenger. Leuven: Uitgeverij Peeters, 2010.

Goldingay, John. Psalms. Baker Commentary on the Old Testament. Grand Rapids, Mich.: Baker Academic, 2006.

Goulder, Michael. "David and Yahweh in Psalms 23 and 24." Journal for the Study of the Old Testament 30/3 (2006): 463-473. 
Groenewald, Alphonso. "Ethics of the Psalms: Psalm 16 within the Context of Psalms 15-24." Journal for Semitics 18/2 (2009): 421-433.

Habel, Norman C. The Book of Job: A Commentary. Philadelphia: Westminster Press, 1985.

Hartley, John E. The Book of Job. Grand Rapids, Mich.: Wm. B. Eerdmans Publishing Co., 1988.

Holter, Knut. "When Biblical Scholars Talk about 'Global' Biblical Interpretation." Pages 85-93 in Global Hermeneutics: Reflections and Consequences. Edited by

Knut Holter and Louis C. Jonker. Atlanta: Society of Biblical Literature, 2010.

Hutton, Jeremy H. The Transjordanian Palimpsest: The Overwritten Texts of Personal Exile and Transformation in the Deuteronomistic History. Berlin: Walter de Gruyter GmbH \& Co. KG, 2009.

Jonker, Louis C. "Revisiting the Psalm Headings: Second Temple Levitical Propaganda." Pages 102-122 in Psalm and Liturgy. Edited by Dirk J. Human and Cas J. A. Vos. London: T\&T Clark International, 2004.

Klein, Naomi. "Democracy Born in Chains: South Africa's Constricted Freedom." Pages 194-217 in The Shock Doctrine: The Rise of Disaster Capitalism. Edited by Naomi Klein. New York: Metropolitan Books, Henry Holt and Company, LLC, 2007.

Knight, Douglas A. Law, Power and Justice in Ancient Israel. Louisville, Ky.: Westminster John Knox Press, 2011.

Lundbom, Jack R. "Psalm 23: Song of Passage." Interpretation 40 (1986): 5-18.

Masenya (ngwan'a Mphahlele), Madipoane. "Sacrificing Female Bodies at the Altar of Male Privilege: A Bosadi (Womanhood) Reading of Judges 19." Journal of Theology and Religion in Africa 27/1 (2003): 98-122.

. "Eating the Louse and Its Larva! The Indignity of Poverty as Embedded within Selected African and Old Testament Proverbs." Scriptura 111/3 (2012): 452-459.

McNutt, Paula. Reconstructing the Society of Ancient Israel. Louisville, Ky.: Westminster John Knox Press, 1999 / London: SPCK, 1999.

Meyer, Esias. "Returning to an Empty Land: Revisiting My Old Argument about Jubilee." Old Testament Essays 27/2 (2014): 502-519.

Modise, Leepo and Ndikho Mtshiselwa. "The Natives Land Act of 1913 Engineered the Poverty of Black South Africans: A Historico-ecclesiastical Perspective." Studia Historiae Ecclesiasticae 39/2 (2013): 359-378.

Mohoebi, Eddie. Forfeiture Unit Seizes 2 KwaZulu-Natal Farms as Department Intensifies Its Fight Against Fraud and Corruption. Pretoria: Department of Rural Development and Land Reforms, 2011.

Mtshiselwa, Ndikho. "Towards an Indigenous (Xhosa) South African Biblical Scholarship." Old Testament Essays 24/3 (2011): 668-689. . "A Post-apartheid Nation in Chains? Relevance of Lucky Dube's Mickey Mouse Freedom in Reconfiguring Forms of Oppression in South Africa Today." Studia Historiae Ecclesiasticae 40/1 (2014): 57-76.

. "A Re-Reading of 1 Kings 21:1-29 and Jehu's Revolution in Dialogue with Farisani and Nzimande: Negotiating Socio-economic Redress in South Africa." Old Testament Essays 27/1 (2014): 205-230.

Ndaliso, Chris. "Land Fraud Case Set for 2012." The Witness (3 October 2011): 1. 
Newham, Gareth. "Why Is Corruption Getting Worse in South Africa?" Page 1. Cited 15 March 2015. Online: http://www.corruptionwatch.org.za/content/whycorruption-getting-worse-south-africa.

Nihan, Christophe. "The Memory of Ezekiel in Postmonarchic Yehud." Pages 415450 in Remembering Biblical Figures in the Late Persian and Early Hellenistic Periods: Social Memory and Imagination. Edited by Diana V. Edelman and Ehud Ben Zvi. Oxford: Oxford University Press, 2013.

Perowne, Stewart J. J. The Book of Psalms. 4th ed. Grand Rapids, Mich.: Zondervan, 1966.

Römer, Thomas. The So-called Deuteronomistic History: A Sociological, Historical and Literary Introduction. London: T\&T Clark International, 2005.

Rowley, Harold H. "The Book of Job and Its Meaning." Bulletin of the John Rylands University Library of Manchester 41 (1958): 167-207.

Schwartz, Baruch J. "Profane' Slaughter and the Integrity of the Priestly Code." Hebrew Union College Annual 67 (1996): 15-42.

Smith, Daniel L. The Religion of the Landless: The Social Context of the Babylonian Exile. Bloomington: Meyer Stone Books, 1989.

Smith, John A. "Which Psalms Were Sung in the Temple?" Music and Letters 71 (1990): 167-186.

Smith-Christopher, Daniel L. A Biblical Theology of Exile. Minneapolis: Fortress Press, 2002.

Statistics South Africa (Stats SA). Social Profile of Vulnerable Groups in South Africa 2002-2011. Pretoria: Statistics South Africa, 2012.

Tanzi, Vito. "Corruption around the World: Causes, Consequences, Scope, and Cures." International Monetary Fund 45/4 (1998): 559-594.

Ukpong, Justin S. "Developments in Biblical Interpretation in Africa: Historical and Hermeneutical Directions." Pages 11-28 in The Bible in Africa: Transactions, Trajectories, and Trends. Edited by Gerald O. West and Musa Dube. Leiden: Brill, 2000.

Vargon, Shmuel. "The Date of Composition of the book of Job in the Context of S.D. Luzzatto's Attitude to Biblical Criticism.” The Jewish Quarterly Review 91/3-4 (2001): 377-394.

West, Gerald O. "Indigenous Exegesis: Exploring the Interface between Missionary Methods and the Rhetorical Rhythms of Africa: Locating Local Reading Resources in the Academy." Neotestamentica 36 (2002): 147-162. . "Locating 'Contextual Bible Study' within Biblical Liberation Hermeneutics and Intercultural Biblical Hermeneutics." HTS Teologiese Studies/Theological Studies 70/1 (2014): 1-10.

Zenger, Erich. Die Nacht wird leuchten wie der Tag: Psalmenauslegungen. Freiburg: Herder, 1997.

Zuma, Jacob G. Written Replies by President Zuma Submitted to Parliament: 30 September 2012. Pretoria: The Presidency, Republic of South Africa, 2012.

Dr. Ndikho Mtshiselwa, Department of Biblical and Ancient Studies, University of South Africa. Email: mtshivnn@unisa.ac.za. 